\title{
Perubahan Mikroklimatik Amonia dan Kondisi Litter Ayam Broiler Periode Starter Akibat Panjang Kandang yang Berbeda
}

\author{
M. R. Saputra, S. Kismiati, T. A. Sarjana* \\ Program Studi Peternakan, Fakultas Peternakan dan Pertanian, Universitas Diponegoro, Semarang, Indonesia \\ 50275
}

\begin{abstract}
ABSTRAK
Penelitian ini dilakukan untuk mengkaji perubahan mikroklimatik amonia dan kondisi litter kandang ayam broiler periode starter (umur 0 sampai 14 hari) akibat ukuran panjang kandang berbeda. Dua unit kandang ayam broiler closed house digunakan dalam penelitian ini dengan kapasitas 11.000 ekor dan 22.000 ekor. Perlakuan dari penelitian ini adalah ukuran panjang kandang closed house yang berbeda $(60 \mathrm{~m}$ dan $120 \mathrm{~m})$. Parameter yang diamati adalah mikroklimatik amonia dan kondisi litter (amonia ekskreta, amonia litter, suhu, $\mathrm{pH}$ dan kadar air litter serta kondisi mikroklimat seperti suhu, kelembaban, kecepatan angin dan Temperature Humidity Index (THI) sebagai data pendukung. Data yang diperoleh selanjutnya di uji Paired T Test. Uji korelasi juga dilakukan pada parameter mikroklimatik amonia dan kondisi litter terhadap kondisi mikroklimat. Hasil penelitian menunjukkan bahwa mikroklimatik amonia, amonia ekskreta, amonia litter, suhu, $\mathrm{pH}$ dan kadar air litter pada kandang $120 \mathrm{~m}$ signifikan $(\mathrm{P} \leq 0,05)$ lebih tinggi daripada kandang $60 \mathrm{~m}$. Hasil uji korelasi menunjukkan mikroklimatik amonia berkorelasi positif kuat dengan kelembaban udara (RH) dan kecepatan angin (AV). Kesimpulannya adalah kandang closed house dengan ukuran panjang $120 \mathrm{~m}$ memiliki mikroklimatik amonia yang lebih tinggi dan kondisi litter yang lebih buruk dibanding kandang $60 \mathrm{~m}$.
\end{abstract}

Kata kunci: Panjang kandang, Kondisi litter, Mikroklimatik amonia, Ayam broiler, Periode starter

\section{Changes in Microclimatic Ammonia and Litter Conditions in Broiler Chicken Starter Periods Due to Different House Lengths}

\begin{abstract}
This research was conducted to examine changes in microclimatic ammonia and litter conditions in broiler chicken starter periods due to different house lengths. Two broilers closed house units were used in this research with a capacity of 11.000 and 22.000 birds. The treatment of this research is the different house lengths $(60 \mathrm{~m}$ and $120 \mathrm{~m})$. The parameters observed were microclimatic ammonia and litter conditions (excreta ammonia levels, ammonia litter levels, litter temperature, litter $\mathrm{pH}$ and litter moisture content) and microclimate conditions such as temperature, relative humidity (RH), air velocity and Temperature Humidity Index (THI) as supporting data. The data obtained were subsequently tested by Paired T-Test. The correlation was also performed on microclimatic ammonia and litter conditions for microclimate conditions. The results showed that microclimatic ammonia, litter temperature, litter $\mathrm{pH}$, litter moisture content, excreta ammonia level and litter ammonia level in the $120 \mathrm{~m}$ house significant $(P \leq 0.05)$ higher than $60 \mathrm{~m}$ houses. Correlation results show that microclimatic ammonia has a strong positive correlation with relative humidity $(\mathrm{RH})$. In conclusion, a closed house with a length of $120 \mathrm{~m}$ has higher microclimatic ammonia and worse litter conditions than $60 \mathrm{~m}$.
\end{abstract}

Keywords: House length, Litter condition, Microclimatic ammonia, Broiler chicken, Starter period

\section{PENDAHULUAN}

Ukuran panjang kandang umumnya menjadi pertimbangan dalam mendirikan kandang closed house. Konsekuensi yang ditimbulkan akibat perbedaan ukuran kandang yang lebih panjang antara lain jarak dari inlet yang lebih panjang, volume kandang yang lebih besar, dan jumlah ternak yang lebih banyak. Perbedaan ukuran panjang kandang dapat berdampak pada perubahan kondisi mikroklimat kandang. Kondisi mikroklimat tak lepas dari pengaruh makroklimat yang merupakan input utama udara yang masuk ke dalam kandang (Sarjana et al. 2018). Input berupa suhu, kelembaban, kecepatan angin dan radiasi matahari dari luar kandang dapat mempengaruhi kondisi mikroklimat

*Penulis Korespondensi: Teysar Adi Sarjana

Alamat: Laboratorium Produksi Ternak Unggas Fakultas

Peternakan dan Pertanian, Universitas Diponegoro, Semarang

E-mail: teysaradisarjana@lecturer.undip.ac.id dalam kandang (Charles, 2002). Peningkatan jumlah populasi ayam berbanding lurus dengan peningkatan ukuran pa njang kandang, artinya semakin banyak populasi ayam maka akan berimplikasi pada peningkatan ukuran panjang kandang yang digunakan. Hal ini berpotensi meningkatkan produksi amonia dikarenakan keluaran ekskreta yang lebih banyak seiring bertambahnya populasi ayam.

Terdapat dua aspek yang setidaknya menyebabkan terjadinya perubahan mikroklimatik amonia. Aspek pertama adalah perubahan kondisi mikroklimat baik suhu, kelembaban, kecepatan angin dan Temperature Humidity Index (THI), hal ini, dapat menimbulkan perubahan mikroklimatik amonia. Mikroklimatik amonia merupakan variasi perubahan mikroklimatik amonia akibat perubahan panjang dan volume kandang (Sarjana et al, 2017). Peningkatan mikroklimatik amonia terjadi akibat adanya perubahan kondisi mikroklimat di dalam kandang antara lain suhu, kelembababan dan kecepatan udara (Lima et al, 2011). 
Penelitian sebelumnya yang dilakukan oleh (Soliman et al, 2017) menunjukkan bahwa mikroklimatik amonia signifikan $(p>0,05)$ berkorelasi negatif terhadap temperatur, artinya terjadinya penurunan temperatur udara akan diikuti dengan peningkatan mikroklimatik amonia. Mikroklimatik amonia juga cenderung meningkat apabila terjadi perubahan kecepatan angin. Kecepatan angin yang rendah menimbulkan disribusi udara segar dari inlet menjadi lebih lambat terbawa menuju outlet dan kurang efisien dalam mengeliminasi amonia.

Aspek yang kedua disebabkan oleh produk metabolit ayam. Menurut (Beker et al. 2004) paparan amonia secara langsung dan kontinyu dapat berdampak pada kondisi internal tubuh ayam yaitu menimbulkan iritasi pada saluran. Ayam akan mengalami stres oksidatif sehingga termoregulasi dan metabolisme terganggu, hal ini menyebabkan inefisiensi dalam penyerapan protein yang berimplikasi pada keluaran nitrogen $(\mathrm{N})$ yang lebih banyak dalam bentuk uric acid. Uric acid selanjutnya akan dikonversi menjadi amonia oleh bakteri ureolitik dengan didukung kondisi lingkungan $\left(\mathrm{O}_{2}\right.$ dan $\left.\mathrm{H}_{2} \mathrm{O}\right)$. Hal tersebut tentunya akan menyebabkan peningkatan mikroklimatik amonia.

Perubahan mikroklimatik amonia juga dapat disebabkan oleh inefisiensi heatloss akibat stres panas. Apabila ayam mengalami stres panas maka konsumsi air minum akan meningkat sehingga memberikan dampak peningkatan kadar air ekskreta. Ekskreta dengan kadar air tinggi yang bercampur dengan litter akan memicu peningkatan kadar air litter. Kadar air litter yang tinggi dan lembab serta didukung dengan $\mathrm{pH}$ dan suhu litter yang tinggi akan meningkatkan kinerja mikroorganisme dalam mendekomposisi protein tidak tercerna dan uric acid menjadi amonia (Knížatová et al. 2010). Hal ini akan menyebabkan peningkatan amonia litter. Kondisi kadar air litter, $\mathrm{pH}$ litter, suhu litter dan amonia litter yang tinggi ini mengindikasikan kondisi litter yang buruk.

Terjadinya perubahan mikroklimatik amonia dan kondisi litter yang buruk dapat memberikan dampak negatif pada ayam broiler. Paparan amonia yang kontinyu pada level 25 ppm menyebabkan iritasi sehingga timbul lesi pada saluran pernafasan ayam (Beker et al. 2004). Hal ini berpotensi menurunkan kemampuan uptake oksigen dan laju metabolisme serta gangguan termoregulasi sehingga feed intake menurun. Hasil penelitian (Yahav, 2004) menunjukkan peningkatan amonia berdampak negatif terhadap kemampuan ayam dalam meregulasikan suhu tubuh, menurunkan feed intake, menurunkan pertambahan bobot badan dan meningkatkan FCR sehingga performans ayam menjadi kurang optimal.

Tujuan dari penelitian ini adalah untuk mengkaji dampak perubahan panjang kandang terhadap mikroklimatik amonia dan kondisi litter kandang ayam broiler periode starter. Hipotesis dari penelitian ini adalah kandang dengan ukuran lebih panjang dapat memberikan dampak pada peningkatan mikroklimatik amonia dan perubahan kondisi litter kandang ayam broiler menjadi lebih buruk.

\section{MATERI DAN METODE}

Penelitian dilaksanakan pada kandang closed house yang memiliki ukuran panjang berbeda $(60 \mathrm{~m}$ dan $120 \mathrm{~m}$ ), dengan lebar yang sama sebesar $12 \mathrm{~m}$ berkapasitas 11.000 dan 22.000 ekor. Penelitian dilakukan selama periode starter $(0-14$ hari). Pakan yang digunakan selama penelitian adalah pakan komersial S10 (0 - 10 hari) dan S11 (11 - 20 hari) serta air minum diberikan menggunakan nipple drinker. Litter berbahan sekam padi digunakan sebagai alas kandang dengan ketebalan litter $\pm 5 \mathrm{~cm}$ dan dilakukan penaburan sekam sesuai standar kemitraan PT. Cemerlang Unggas Lestari. Perlakuan yang diterapkan adalah membandingkan dua unit kandang dengan ukuran panjang berbeda, ditempatkan 20 unit titik pengamatan sebagai ulangan. Parameter yang diamati adalah mikroklimatik amonia, kadar amonia ekskreta, kadar amonia litter, suhu litter, $\mathrm{pH}$ litter dan kadar air litter. Data kondisi mikroklimat juga diambil sebagai data pendukung meliputi suhu, kelembaban, kecepatan angin dan Temperature Humidity Index (THI).

Data mikroklimatik amonia, kadar amonia ekskreta dan amonia litter diamati dengan menggunakan alat ammonia detector yang pada prinsipnya mendeteksi kandungan gas amonia ambient. Mikroklimatik amonia diukur $25 \mathrm{~cm}$ dari litter dengan ammonia detector, sedangkan amonia ekskreta dan amonia litter menggunakan sampel ekskreta dan litter sebanyak 20 gram yang dimasukkan ke dalam modified ammonia chamber lalu diukur dengan ammonia detector dalam keadaan tertutup sampai menunjukkan angka tingkat konsentrasi gas amonia yang muncul. Data suhu litter diukur dengan infrared thermometer yang memiliki prinsip dasar mendeteksi suhu berdasarkan radiasi energi inframerah dari suatu objek,

Tabel 1. Rata-rata kondisi makroklimat dan mikroklimat pada panjang kandang closed house berbeda

\begin{tabular}{lcc}
\hline \hline Makroklimat & Nilai \\
\hline Suhu $\left({ }^{\circ} \mathrm{C}\right)$ & \multicolumn{2}{c}{27,6} \\
Kelembaban $(\%)$ & 79,4 \\
Kecepatan Angin $(\mathrm{m} / \mathrm{s})$ & \multicolumn{2}{c}{1,5} \\
Curah Hujan* $(\mathrm{mm})$ & \multicolumn{2}{c}{2,7} \\
Radiasi Matahari $\left(\mathrm{W} / \mathrm{m}^{2}\right)$ & \multicolumn{2}{c}{267,7} \\
\hline \multirow{2}{*}{ Mikroklimat } & \multicolumn{2}{c}{ Rata-rata } \\
\cline { 2 - 3 } & $60 \mathrm{~m}$ & $120 \mathrm{~m}$ \\
\hline Suhu $\left({ }^{\circ} \mathrm{C}\right)$ & 30,40 & 29,80 \\
Kelembaban $(\%)$ & 81,90 & 83,60 \\
Kecepatan Angin $(\mathrm{m} / \mathrm{s})$ & 1,70 & 1,60 \\
Temperature Humidity & 38,84 & 38,88 \\
Index $($ THI) & \\
\hline
\end{tabular}


semakin panas suatu objek maka molekulnya semakin aktif dan energi inframerah yang dipancarkan semakin besar. Data $\mathrm{pH}$ litter diukur dengan metode potensiometri yang pada prinsipnya kadar $\mathrm{pH}$ diukur berdasarkan aktivitas ion hidrogen secara potensiometri dengan menggunakan $\mathrm{pH}$ meter. Sampel yang digunakan yaitu litter dengan konsentrasi 2\% (2 gram litter dalam $100 \mathrm{ml}$ aquades). Kadar air litter diukur dengan metode gravimetri (pengeringan dengan oven) menggunakan sampel litter sebanyak 10 gram lalu di oven pada suhu $105^{\circ} \mathrm{C}$ selama 6 jam untuk mengetahui berat kering. Hasil perhitungan kadar air litter didapat dari selisih antara berat basah dan berat kering dibagi berat basah dikali $100 \%$ (AOAC, 1995). Data mikroklimat berupa suhu, kelembaban, kecepatan angin dan THI diukur dengan alat Kestrel ${ }^{T M}$ yang dilakukan pada hari ke 3, 7, 10 dan 14. Berikut disajikan data rata-rata kondisi makroklimat dan mikroklimat (Data penelitian bersama, 2018) pada Tabel 1.

Data yang diperoleh selanjutnya di uji Paired $T$ Test dan uji korelasi. Korelasi antara kondisi mikroklimat terhadap mikroklimatik amonia dan kondisi litter juga dilakukan untuk mengkaji kontribusi pengaruh kondisi mikroklimat terhadap perubahan kondisi litter kandang ayam broiler.

\section{HASIL DAN PEMBAHASAN}

Hasil uji Paired $T$ Test menunjukkan pertambahan ukuran panjang kandang signifikan $(\mathrm{P} \leq 0,05)$ meningkatkan mikroklimatik amonia, amonia ekskreta, amonia litter, suhu, $\mathrm{pH}$ dan kadar air litter pada periode starter. Data hasil uji Paired T Test disajikan pada Tabel 2.

\section{Kadar Air Litter}

Kadar air litter mengalami peningkatan yang signifikan $(\mathrm{P} \leq 0,05)$ pada kandang $120 \mathrm{~m}$ diduga akibat 2 aspek. Aspek pertama adalah produk metabolit ayam. Terjadi inefisiensi penyerapan protein pada ayam karena stres oksidatif akibat paparan amonia memberikan dampak pada keluaran nitrogen $(\mathrm{N})$ lebih banyak. Keluaran N yang lebih banyak lazimnya akan berimplikasi pada peningkatan amonia ekskreta dan kadar air ekskreta. Peningkatan kadar air ekskreta diduga juga terjadi karena kontribusi peningkatan konsumsi air minum akibat cekaman panas

Tabel 2. Mikroklimatik amonia, amonia ekskreta dan kondisi litter periode starter pada panjang kandang closed house berbeda

\begin{tabular}{|c|c|c|c|c|}
\hline \multirow{2}{*}{ Parameter } & \multirow{2}{*}{ Hari } & \multicolumn{2}{|c|}{ Rata-Rata } & \multirow{2}{*}{ P Value } \\
\hline & & $60 \mathrm{~m}$ & $120 \mathrm{~m}$ & \\
\hline \multirow[t]{4}{*}{ Kadar Air Litter } & 3 & $16,02 \pm 5,41^{b}$ & $20,89 \pm 5,58^{a}$ & 0,01 \\
\hline & 7 & $21,01 \pm 4,21$ & $22,87 \pm 6,23$ & 0,20 \\
\hline & 10 & $21,36 \pm 2,43^{b}$ & $22,98 \pm 3,11^{\mathrm{a}}$ & 0,01 \\
\hline & 14 & $21,91 \pm 2,76$ & $23,00 \pm 3,14$ & 0,08 \\
\hline \multirow[t]{4}{*}{$\mathrm{pH}$ Litter } & 3 & $7,57 \pm 0,46^{\mathrm{b}}$ & $8,92 \pm 0,55^{\mathrm{a}}$ & 0,00 \\
\hline & 7 & $8,04 \pm 0,85^{\mathrm{a}}$ & $8,60 \pm 0,71^{\mathrm{a}}$ & 0,02 \\
\hline & 10 & $8,94 \pm 0,52$ & $9,13 \pm 0,69$ & 0,34 \\
\hline & 14 & $9,12 \pm 0,81$ & $9,33 \pm 0,41$ & 0,24 \\
\hline \multirow[t]{4}{*}{ Suhu Litter } & 3 & $32,72 \pm 1,20$ & $32,88 \pm 0,35$ & 0,52 \\
\hline & 7 & $30,92 \pm 0,92$ & $31,11 \pm 1,06$ & 0,45 \\
\hline & 10 & $29,44 \pm 1,04^{\mathrm{b}}$ & $30,46 \pm 1,09^{a}$ & 0,00 \\
\hline & 14 & $30,19 \pm 0,68^{\mathrm{b}}$ & $31,13 \pm 0,60^{\mathrm{a}}$ & 0,00 \\
\hline \multirow[t]{4}{*}{ Amonia Ekskreta } & 3 & $1,50 \pm 0,61^{\mathrm{b}}$ & $2,40 \pm 1,47^{\mathrm{a}}$ & 0,03 \\
\hline & 7 & $3,15 \pm 1,50$ & $3,95 \pm 1,64$ & 0,11 \\
\hline & 10 & $3,60 \pm 1,44^{\mathrm{b}}$ & $7,00 \pm 1,26^{\mathrm{a}}$ & 0,00 \\
\hline & 14 & $4,65 \pm 1,35^{\mathrm{b}}$ & $7,45 \pm 1,00^{\mathrm{a}}$ & 0,00 \\
\hline \multirow[t]{4}{*}{ Amonia Litter } & 3 & $1,55 \pm 0,69^{b}$ & $3,00 \pm 1,21^{\mathrm{a}}$ & 0,00 \\
\hline & 7 & $2,90 \pm 0,91$ & $3,55 \pm 1,64$ & 0,16 \\
\hline & 10 & $4,05 \pm 1,67^{b}$ & $5,65 \pm 1,31^{\mathrm{a}}$ & 0,00 \\
\hline & 14 & $6,40 \pm 1,35$ & $7,05 \pm 1,39$ & 0,17 \\
\hline \multirow[t]{4}{*}{ Mikroklimatik Amonia } & 3 & $1,07 \pm 0,41^{\mathrm{b}}$ & $2,15 \pm 0,55^{\mathrm{a}}$ & 0,00 \\
\hline & 7 & $1,27 \pm 0,37^{\mathrm{b}}$ & $2,40 \pm 0,60^{\mathrm{a}}$ & 0,00 \\
\hline & 10 & $1,56 \pm 0,40^{\mathrm{b}}$ & $2,54 \pm 0,63^{a}$ & 0,00 \\
\hline & 14 & $2,42 \pm 0,86^{\mathrm{b}}$ & $3,37 \pm 0,98^{\mathrm{a}}$ & 0,00 \\
\hline
\end{tabular}

$\overline{\mathrm{a}, \mathrm{b}, \mathrm{c}}$ superskrip berbeda pada baris yang sama menunjukkan perbedaan yang nyata $(\mathrm{P} \leq 0,05)$, ns (non significant) $=$ berbeda tidak nyata $(\mathrm{P}>0,05)$. $60 \mathrm{~m}$ = kandang closed house dengan ukuran panjang $60 \mathrm{~m}, 120 \mathrm{~m}=$ kandang closed house dengan ukuran panjang $120 \mathrm{~m}$ 
sebagaimana hasil penelitian Yahav (2004) yang menunjukkan bahwa cekaman panas terjadi karena masalah kegagalan termoregulasi akibat adanya peningkatan amonia. Hasil penelitian Tamzil et al. (2013) menunjukkan bahwa ayam yang mengalami heat stress selama 1 jam maka akan terjadi peningkatan konsumsi air minum sebanyak 0,57 ml/ekor/menit dan kadar air ekskreta meningkat sebesar 18,27 \%. Terjadinya peningkatan kadar air ekskreta menimbulkan litter menjadi lebih basah sehingga memberikan dampak peningkatan kadar air litter.

Aspek yang kedua adalah adanya perubahan kondisi mikroklimat khususnya suhu, kelembaban dan THI. Perubahan suhu, kelembaban dan THI terjadi karena terdapat perbedaan ukuran panjang kandang yang berimplikasi pada jarak yang lebih panjang sehingga distribusi aliran udara akan berbeda. Sarjana et al. (2018) menyatakan bahwa perubahan mikroklimat dalam kandang baik suhu, kelembaban, THI dapat terjadi akibat perubahan panjang kandang. Perbedaan distribusi aliran udara dari inlet diduga berkontribusi dalam terjadinya perubahan kondisi mikroklimat karena pada kandang yang lebih panjang memiliki jarak lebih jauh dari inlet menuju outlet. Berdasarkan hasil korelasi yang telah dilakukan menunjukkan kadar air litter berkorelasi negatif kuat dengan suhu dan THI, yang berarti bahwa penurunan suhu dan THI berkontribusi terhadap peningkatan kadar air litter. Liu et al. (2007) menyatakan bahwa kadar air litter dipengaruhi oleh banyak faktor salah satunya adalah ventilasi di dalam kandang. Ventilasi di dalam kandang berperan besar dalam perubahan suhu dan THI dimana akan berdampak pada perubahan kadar air litter kandang. Ritz et al. (2004) menyatakan bahwa adanya peningkatan kelembaban udara dan manajemen drinking system juga dapat berpengaruh pada peningkatan kadar air litter.

\section{pH Litter}

Peningkatan $\mathrm{pH}$ litter yang signifikan $(\mathrm{P} \leq 0,05)$ pada kandang $120 \mathrm{~m}$ diduga terjadi karena adanya keluaran $\mathrm{N}$ yang lebih banyak. Nitrogen yang pada dasarnya bersifat basa, akan meningkatkan $\mathrm{pH}$ apabila bercampur dengan litter. Abreu et al. (2011) menyatakan bahwa tingginya kandungan $\mathrm{N}$ ekskreta yang terdapat pada litter dapat memicu peningkatan $\mathrm{pH}$ litter. $\mathrm{N}$ ekskreta dalam bentuk uric acid akan dikonversi oleh bakteri ureolitik dengan didukung kondisi lingkungan $\left(\mathrm{H}_{2} \mathrm{O}\right.$ dan $\left.\mathrm{O}_{2}\right)$ sehingga menghasilkan $\mathrm{NH}_{3}$ dan $\mathrm{CO}_{2}$. Patterson dan Adrizal (2005) menyatakan bahwa uric acid yang dikonversi oleh bakteri ureolitik akan menghasilkan 4 molekul $\mathrm{NH}_{3}$, hal ini tentunya akan berdampak pada peningkatan $\mathrm{pH}$ litter.

Adanya perubahan kelembaban $(\mathrm{RH})$ yang terjadi pada kandang $120 \mathrm{~m}$ turut berkontribusi dalam meningkatkan $\mathrm{pH}$ litter dalam kandang. Hasil korelasi menunjukkan $\mathrm{pH}$ litter signifikan $(\mathrm{P} \leq 0,01)$ berkorelasi positif kuat $(r>0,5)$ dengan kelembaban $(\mathrm{RH})$ yang berarti peningkatan kelembaban $(\mathrm{RH})$ berpengaruh besar pada peningkatan $\mathrm{pH}$ litter dalam kandang. Hal ini sesuai dengan penelitian Sarjana et al. (2017) yang menyatakan bahwa terdapat hubungan yang signifikan dan positif antara kelembaban dan $\mathrm{pH}$ litter. Hal ini juga dikonfirmasi Liu et al. (2007) yang menyatakan bahwa kelembaban udara yang tinggi menimbulkan litter menjadi lembab sehingga meningkatkan aktivitas bakteri dalam mengkonversi uric acid menjadi amonia. Semakin banyak molekul amonia yang terkandung di litter tentunya akan berdampak pada peningkatan $\mathrm{pH}$ litter.

\section{Suhu Litter}

Peningkatan suhu litter yang signifikan $(\mathrm{P} \leq 0,05)$ pada kandang $120 \mathrm{~m}$ diduga terjadi karena perubahan kondisi mikroklimat kandang khususnya kecepatan angin. Terjadinya perubahan kecepatan angin yang lebih rendah pada kandang $120 \mathrm{~m}$ menjadi faktor penyebab peningkatan suhu dalam kandang. Kandang $120 \mathrm{~m}$ memiliki panjang dan volume yang lebih besar sehingga kecepatan distribusi udara segar dari inlet akan lebih rendah dan kurang efisien. Hal tersebut yang

Tabel 3. Nilai r value antara kondisi mikroklimat dengan mikroklimatik amonia, amonia ekskreta dan kondisi litter

\begin{tabular}{llcccc}
\hline \hline Panjang Kandang & & Suhu & RH & AV & THI \\
\hline $60 \mathrm{~m}$ & Suhu Litter & $0,24^{*}$ & $-0,59^{* *}$ & $-0,43^{* *}$ & $0,54^{* *}$ \\
& pH Litter & 0,10 & $0,24^{*}$ & 0,13 & 0,05 \\
& Kadar Air Litter & $-0,24^{*}$ & $0,45^{* *}$ & 0,20 & $-0,28^{*}$ \\
& Amonia Litter & $-0,07$ & 0,17 & $0,31^{* *}$ & $-0,33^{* *}$ \\
& Amonia Ekskreta & $-0,06$ & $0,52^{* *}$ & $0,28^{*}$ & $-0,26^{*}$ \\
& Mikroklimatik Amonia & 0,04 & $0,44^{* *}$ & 0,17 & $-0,11$ \\
& Suhu Litter & $0,65^{* *}$ & $-0,53^{* *}$ & $-0,32^{* *}$ & $0,58^{* *}$ \\
& pH Litter & $-0,23^{*}$ & $0,50^{* *}$ & $0,32^{* *}$ & $-0,06$ \\
& Kadar Air Litter & $-0,25^{*}$ & 0,09 & $-0,02$ & $-0,26^{*}$ \\
& Amonia Litter & $-0,32^{* *}$ & $0,32^{* *}$ & $0,65^{* *}$ & $-0,31^{* *}$ \\
& Amonia Ekskreta & $-0,36^{* *}$ & $0,52^{* *}$ & $0,61^{* *}$ & $-0,29^{* *}$ \\
& Mikroklimatik Amonia & $-0,01$ & $0,24^{*}$ & $0,23^{*}$ & $0,22^{*}$ \\
\hline
\end{tabular}

Keterangan: $*=$ Korelasi signifikan pada taraf $5 \%$; ** = Korelasi signifikan pada taraf $1 \%$ 
menyebabkan terjadinya peningkatan suhu dalam kandang yang berakibat pada peningkatan suhu litter karena adanya perpindahan panas secara konveksi antara udara dan litter. Hal ini sesuai dengan penelitian Sarjana et al. (2018) yang menyatakan bahwa perubahan ukuran panjang dan volume kandang menimbulkan perubahan suhu udara akibat kecepatan distribusi udara yang berubah, suhu udara yang meningkat tentunya akan berimplikasi pada peningkatan suhu litter yang disebabkan oleh adanya perpindahan panas secara konveksi dari udara ke litter. Penelitian Baracho et al. (2011) juga mengkonfirmasi hal tersebut bahwa peningkatan suhu udara juga berdampak pada kenaikan temperatur tubuh ayam, untuk menjaga suhu tubuh ayam agar tetap ideal maka ayam akan melakukan pembuangan panas berlebih secara kontak langsung antara tubuh ayam dengan litter. Hal ini tentunya akan menimbulkan suhu litter meningkat.

Perubahan suhu litter didukung dengan hasil korelasi yang menunjukkan bahwa suhu litter berkorelasi positif kuat dengan suhu dan THI, sebaliknya pada kelembaban (RH) dan kecepatan angin (AV) berkorelasi negatif. Hal ini sesuai dengan pendapat Field (2009) yang menyatakan bahwa kuatnya pengaruh hubungan antar parameter ditunjukkan dengan nilai r yang signifikan baik negatif maupun positif. Hal tersubut menunjukkan apabila terjadi peningkatan suhu dan THI maka akan diikuti dengan peningkatan suhu litter dalam kandang, sebaliknya peningkatan pada kelembaban $(\mathrm{RH})$ dan kecepatan angin (AV) memberikan pengaruh besar pada penurunan suhu litter. Knížatová et al. (2010) juga mengkonfirmasi hal tersebut bahwa perubahan mikroklimat dalam kandang baik peningkatan suhu, kelembaban, kecepatan angin, THI dan pencahayaan dapat meningkatkan suhu litter kandang.

\section{Amonia Ekskreta}

Amonia ekskreta pada kandang $120 \mathrm{~m}$ mengalami peningkatan yang signifikan $(\mathrm{P} \leq 0,05)$ diduga karena peningkatan nitrogen $(\mathrm{N})$ ekskreta akibat keluaran $\mathrm{N}$ yang lebih banyak. Apabila kandungan $\mathrm{N}$ ekskreta semakin banyak maka akan lebih banyak $\mathrm{N}$ yang dikonversi menjadi amonia oleh bakteri. Hal tersebut tentunya akan meningkatkan amonia ekskreta. Hal ini sesuai dengan pendapat Coufal et al. (2006) yang menyatakan bahwa semakin besar kandungan nitrogen dalam ekskreta akan berimplikasi pada peningkatan amonia ekskreta. Bobrutzki et al. (2013) juga mengkonfirmasi dugaan tersebut bahwa peningkatan nitrogen $(\mathrm{N})$ output pada ekskreta dapat menyebabkan peningkatan amonia ekskreta.

Perubahan kondisi mikroklimat khususnya $\mathrm{RH}$ dan AV pada kandang $120 \mathrm{~m}$ diduga juga meningkatkan amonia ekskreta. Kelembaban yang tinggi akan menimbulkan kadar air cenderung meningkat sehingga mendukung ketersediaan $\mathrm{H}_{2} \mathrm{O}$ yang diperlukan bakteri ureolitik dalam mengkonversi uric acid menjadi amonia. Berdasarkan hasil korelasi yang telah dilakukan menunjukkan amonia ekskreta berkorelasi positif kuat dengan RH dan AV yang berarti peningkatan kelembabaan dan kecepatan angin akan diikuti dengan peningkatan amonia ekskreta. Hal tersebut sesuai dengan beberapa penelitian sebelumnya (Coufal, 2005; Ritz et al. 2014; Alloui et al. 2013) yang menyatakan bahwa temperatur, kelembaban dan kecepatan udara serta ventilasi dalam kandang memiliki pengaruh besar pada kadar amonia ekskreta dalam kandang.

\section{Amonia Litter}

Amonia litter pada kandang $120 \mathrm{~m}$ mengalami peningkatan yang signifikan $(\mathrm{P} \leq 0,05)$ diduga karena dampak dari adanya peningkatan amonia ekskreta. Litter di dalam kandang umumnya sudah bercampur dengan ekskreta. Apabila amonia ekskreta meningkat maka amonia litter juga akan ikut meningkat. Tinggi rendahnya amonia ekskreta bergantung pada level nitrogen yang terkandung di dalam ekskreta. Hal ini sesuai dengan pendapat Maliselo dan Mwaanga (2016) menyatakan bahwa kadar amonia pada litter tak lepas dari pengaruh nitrogen ekskreta yang berperan sebagai prekursor pembentukan amonia. Selain itu, perubahan suhu, kelembaban, kecepatan angin dan THI di dalam kandang diduga juga berkontribusi meningkatkan amonia litter. Hasil korelasi menunjukkan bahwa amonia litter berkorelasi positif kuat dengan kelembaban (RH) dan kecepatan angin (AV), sebaliknya berkorelasi negatif cukup kuat dengan suhu dan THI. Hal ini menunjukkan dengan adanya peningkatan kelembaban $(\mathrm{RH})$ dan kecepatan angin (AV) akan diikuti dengan peningkatan amonia litter, sebaliknya penurunan suhu dan THI akan diikuti dengan peningkatan amonia litter. Kelembaban yang tinggi menimbulkan kondisi litter lembab sehingga mendukung aktivitas bakteri dalam mengkonversi uric acid menjadi amonia. Hal tersebut dikonfirmasi oleh Miles et al. (2011) yang menyatakan bahwa kondisi litter yang lembab memberikan kondisi yang optimal bagi bakteri untuk mengubah uric acid menjadi amonia sehingga memberikan dampak peningkatan amonia litter.

\section{Mikroklimatik Amonia}

Terdapat 2 aspek yang diduga menyebabkan peningkatan mikroklimatik amonia pada kandang 120 m. Aspek pertama adalah produk metabolit ayam. Terjadinya inefisiensi penyerapan protein yang berdampak pada keluaran $\mathrm{N}$ yang lebih banyak sehingga berpotensi meningkatkan mikroklimatik amonia. Komponen dasar prekursor amonia berupa N, apabila jumlahnya semakin banyak, maka semakin banyak pula yang terkonversi menjadi amonia. Hal ini sesuai dengan pendapat (Maliselo dan Nkonde, 2015) menyatakan bahwa tinggi rendahnya kandungan $\mathrm{N}$ ekskreta dapat mempengaruhi tingkat mikroklimatik amonia. Hasil penelitian Patterson dan Adrizal (2005) menyatakan bahwa $\mathrm{N}$ ekskreta dalam bentuk uric acid yang bercampur dengan litter akan dikonversi menjadi 
amonia oleh bakteri ureolitik (Corynebacterium) dengan bantuan $\mathrm{O}_{2}$ dan $\mathrm{H}_{2} \mathrm{O}$ menghasilkan 4 molekul $\mathrm{NH}_{3}$ dan 5 molekul $\mathrm{CO}_{2}$. Hal ini tentunya akan berimplikasi pada peningkatan mikroklimatik amonia.

$$
\begin{array}{lll}
\mathrm{C}_{5} \mathrm{H}_{4} \mathrm{O}_{3} \mathrm{~N}_{4}+1,5 \mathrm{O}_{2}+4 \mathrm{H}_{2} \mathrm{O} & \rightarrow & 4 \mathrm{NH}_{3}+5 \mathrm{CO}_{2} \\
\text { (uric acid) } & \text { (bakteri ureolitik) }
\end{array}
$$

Proses pembentukan amonia (Patterson and Adrizal, 2005)

Aspek yang kedua adalah adanya perubahan kondisi mikroklimat pada panjang kandang yang berbeda. Perubahan kondisi mikroklimat khususnya kelembaban dan kecepatan angin diduga juga berkontribusi meningkatkan mikroklimatik amonia. Mikroklimatik amonia terbentuk karena proses volatilisasi amonia. Volatilisasi dapat terjadi secara optimal apabila didukung dengan kondisi mikroklimat dan lingkungan yang sesuai. Berdasarkan hasil korelasi yang kami lakukan menunjukkan bahwa mikroklimatik amonia berkorelasi positif kuat dengan kelembaban (RH) dan kecepatan angin (AV). Hal ini menunjukkan peningkatan yang terjadi pada kelembaban dan kecepatan angin akan diikuti dengan peningkatan mikroklimatik amonia di dalam kandang. Hal ini sesuai dengan pendapat Soliman et al. (2017) yang menyatakan bahwa perubahan kondisi mikroklimat berupa kecepatan angin yang lebih rendah dapat berdampak pada eliminasi amonia yang kurang efisien sehingga mikroklimatik amonia meningkat. Berdasarkan hasil kalkulasi yang dilakukan diketahui bahwa kemampuan eliminasi amonia pada kandang 60 $\mathrm{m}$ dan $120 \mathrm{~m}$ sebesar $0,02 \mathrm{~m}^{3} / \mathrm{jam}$ dan $0,03 \mathrm{~m}^{3} / \mathrm{jam}$. Hal ini menunjukkan bahwa kemampuan eliminasi amonia pada kandang $120 \mathrm{~m}$ lebih besar. Namun peningkatan tersebut belum sebanding dengan peningkatan perubahan volume kandang. Hal tersebut sesuai dengan pendapat Bobrutzki et al. (2013) yang menyatakan bahwa terjadinya variasi amonia sangat dipengaruhi oleh ventilation rate yang berperan penting dalam eliminasi amonia di dalam kandang.

\section{KESIMPULAN}

Kesimpulan dari penelitian ini adalah kandang closed house dengan ukuran panjang $120 \mathrm{~m}$ memiliki mikroklimatik amonia yang lebih tinggi dan kondisi litter yang lebih buruk dibanding kandang $60 \mathrm{~m}$.

\section{UCAPAN TERIMA KASIH}

Penulis mengucapkan terimakasih kepada Fakultas Peternakan dan Pertanian Universitas Diponegoro yang telah mendukung pelaksanaan penelitian ini dengan penyediaan fasilitas penelitian berupa kandang closed house dan bantuan dana penelitian.

\section{DAFTAR PUSTAKA}

Abreu, V., P. Abreu, F. Jaenisch, A. Coldebella and D. Paiva. 2011. Effect of floor type (dirt or concrete) on litter quality, house environmental conditions, and performance of broilers. Brazilian Journal of Poultry Science 13(2): 127-137.

Alloui, N., M. Alloui, O. Bennoune and S. Bouhentala. 2013. Effect of ventilation and atmospheric ammonia on the health and performance of broiler chickens in summer. Journal of World's Poultry Research 3(2): 54-56.

AOAC. 1995. Official Method of Analysis of the Association of Official Analytical Chemist. 17th ed. AOAC:13. Washington D.C.

Baracho, M., I.A. Naas, G.R. Nascimento, J.A. Cassiano and K.R. Oliveira. 2011. Surface temperature distribution in broiler houses. Brazilian Journal of Poultry Science 13(3): 177182.

Bobrutzki, K. V., C. Ammon, W. Berg and M. Fiedler. 2013. Quantification of nitrogen balance components in a commercial broiler barn. Czech Journal of Animal Science 58(12): 566-577.

Coufal, C. D. 2005. Quantification of Litter Production and The Fate of Nitrogen in Commercial broiler Production Systems. Dissertation. Texas A and M University. USA.

Coufal, C. D., C. Chavez, P.R. Niemeyer and J.B. Carey. 2006. Nitrogen emissions from broilers measured by mass balance over eighteen consecutive flocks. Poultry Science 85(3): 384391.

Field, A. 2009. Discovering Statistics Using SPSS. 3rd ed. SAGE Publications Ltd. London.

Knížatová, M., S. Mihina, J. Broucek, I. Karandusovska and J. Macuhova. 2010. The influence of litter age, litter temperature and ventilation rate on ammonia emissions from a broiler rearing facility. Czech Journal of Animal Science 55(8): 337-345.

Lima, K. A.O., D.J. Moura, T.M.R. Carvalho, L.G.F. Bueno and R.A. Vercellino. 2011. Ammonia emissions in tunnel-ventilated broiler houses. Brazillian Journal of Poultry Science 13(4): 265-270.

Liu, Z., L. Wang, D. Beasley and E. Oviedo. 2007. Effect of moisture content on ammonia emissions from broiler litter: A laboratory study. Journal of Atmospheric Chemistry 58(1): 41-53.

Maliselo, P.S. and G.K. Nkonde. 2015. Ammonia production in poultry houses and its effect on the growth of gallus gallus domestica (Broiler Chickens): A case study of a small scale poultry house in Riverside, Kitwe, Zambia. International Journal of Scientific \& Technology Research 4(4): 141-145.

Maliselo, S. and P. Mwaanga. 2016. Effects of pH, 
moisture and excreta age on ammonia emission in a poultry house: A case study for Kitwe, Zambia. International Journal of Scientific and Research Publications 6(8): 73-76.

Miles, D.M., D.E. Rowe and T.C. Cathcart. 2011. Litter ammonia generation: moisture content and organic versus inorganic bedding materials. Poultry Science 90(6): 1162-1169.

Patterson, P.H. and Adrizal. 2005. Management strategies to reduce air emissions: emphasis-dust and ammonia. Journal of Applied Poultry Research 14(3): 638-650.

Ritz, C.W., B.D. Fairchild and M.P. Lacy. 2014. Implications of ammonia production and emissions from commercial poultry facilities: A Review. The Journal of Applied Poultry Research 13(4): 684-692.

Sarjana, T.A., L.D. Mahfudz, D. Winarti, W. Sarenggat, N.K.F. Huda, N.A. Rahma, Renata, D.A. Suryani, W.F. Arfianta dan B. Mustaqim. 2018. Perbedaan kondisi mikroklimat akibat zona penempatan di closed house ayam broiler. Prosiding Seminar Nasional Kebangkitan Peternakan III Hilirisasi Teknologi Peternakan pada Era Revolusi Industri 4. Semarang,
Indonesia. pp. 688-700.

Sarjana, T.A., L.D. Mahfudz, M. Ramadhan, Sugiharto, F. Wahyono dan S. Sumarsih. 2017. Emisi amonia dan kondisi litter pada kandang ayam broiler sistem terbuka yang mendapatkan additif berbeda dan kombinasinya dalam ransum Prosiding Seminar Nasional Pengembangan Peternakan Berkelanjutan ke-9. Tantangan Dunia Peternakan dalam Meningkatkan Nilai Tambah dan Daya Saing Sumber Daya Genetik Ternak Lokal. Jatinangor, Indonesia. pp. 593-599.

Soliman, E.S., S.A. Moawed and R.A. Hassan. 2017. Influence ofmicroclimatic ammonia levels on productive performance of different broilers breeds estimated with univariate and multivariate approaches. Veterinary World 10(8): 880-887.

Tamzil, M.H., R.R. Noor, P.S. Hardjosworo, W. Manalu and C. Sumantri. 2013. Acute heat stress responses of three lines of chickens with different heat shock protein (HSP)-70 Genotypes. International Journal of Poultry Science 12(5): 264-272.

Yahav, S. 2004. Ammonia affects performance and thermoregulation of male broiler chickens. Animal Research, EDP Science 53(4): 289-293. 